by all advanced students of both botany and chemistry, since it covers a more extensive field than any other work on vegetable chemistry published in English in recent years, and provides a compendium of information such as has hitherto been available only in the form of numerous separate monographs or in encyclopædias like those of Czapel, Wehmer, and Abderhalden, to mention only some of the recent biochemical compilations.

The book appears to be remarkably free from misprints, though "Priestly" occur's several times instead of "Priestley," and there are a few cases in which the same substance is given different names without any indication that these are examples of the richness of chemical nomenclature in synonymy- "orcin" and "orcinol" in successive paragraphs on p. 56, for instance. The book is exceedingly well got up, is published at an extremely moderate price, and will undoubtedly meet with a wide welcome as an indispensable work to all students of plant physiology.

F.C.

\title{
VEGETATION OF THE ENGADINE.
}

“Pflanzengeographische Monographie des Berninagebietes," by Dr. E. RüBel. Leipzig (W. Engelmann), 1912. Price 8 Marks.

THIS valuable and voluminous monograph may be taken as one 1 of the best examples of an excellent series of works (1) on the vegetation of Switzerland by the phytogeographers of that interesting and beautiful country. The work is in two volumes, the first containing nearly 300 pages and the second rather more. The work begins with short accounts of the ecological factors, the climate, and the geological structure (by Dr. E. Blösch), and goes on to give a very full account of the vegetation. The second volume is of the nature of a Flora, and includes the mosses (by Dr. Th. Herzog), the lichens (by Professor G. Lindau), the fungi (by Dr. A. Volkart), and the plankton (by Dr. G. Huber). It will be seen therefore that $\mathrm{Dr}$. Rübel has supplied botanists with a very comprehensive phytogeographical account of the Engadine.

This district is known to a not inconsiderable number of British tourists; and the writer had the pleasure a few years ago of being conducted by $\mathrm{Dr}$. Rübel over many parts of the area. The Engadine is in the south-eastern portion of Switzerland, on the confines of Austria and Italy, and is one of the richest floristic grounds in Europe. The highest altitude reached in the Engadine is the summit of the Piz Bernina, 4,055 m. (13,300 feet), and the lowest-near Samaden-1,700 m. (5,580 feet). It will be seen therefore that the whole district lies in the sub-Alpine and Alpine zones. $^{1}$ The rainfall varies from $63 \mathrm{~cm}$. (25 inches) at Belvoir, to

1 Wahlenberg's (1811) “lower Alpine zone" begins at 1,789 m., his " higher Alpine zone " at 2,112 m., and his " niveal zone"" at $2,675 \mathrm{~m}$., Christ's (1907) "zone of coniferous forests" begins at $1,80 \mathrm{~m}$. (for northern Switzerland) and 2,100 m. (for southern Switzerland), and his Alpine zone at $2,700 \mathrm{~m}$. (for northern Switzerland) and 3,000 m. (for southern Switzerland). 
$90 \mathrm{~cm}$. (36 inches) at Pontresina, and $160 \mathrm{~cm}$. (63 inches) at the Bernina Hospice-these being averages for five years.

The average snow-limit of the district is given at $2,960 \mathrm{~m}$. $(9,710$ feet). The highest larch (Larix decidua) attains an altitude of $2,660 \mathrm{~m}$. (8,730 feet), ${ }^{1}$ and the highest Arolla pine (Pinus cembra) $2,580 \mathrm{~m}$. $(8,470$ feet $)$. The average dwarf-tree limit is put at $2,400 \mathrm{~m}$. $(7,870 \mathrm{feet})$, and the average tree-limit at from 2,200 to $2,250 \mathrm{~m}$. (7,220 to 7,380 feet $)$.

In addition to numerous excellent photographic illustrations of the vegetation, a beautiful coloured vegetation map accompanies the first volume, the colours being superimposed on the Swiss topographical map $(1: 50,000)$. As is well-known, these Swiss maps are perhaps the best in the world, as regards clearness, physiographical detail, and contouring. The maps of the Peak District-even the six-inch maps-compare most unfavourably with those issued by the Swiss authorities; and as I have recently worked with the British ordnance maps of the Peak District I may claim to know their virtues and their shortcomings.

Dr. Rübel's map is constructed on rather different lines from British vegetation maps. British vegetation maps are fully coloured: Dr. Rübel's map leaves the ice-covered areas and the boulder-covered areas uncoloured. However, as these areas are well depicted on the topographical maps themselves, there is no disadvantage in the plan adopted; and, besides, it materially reduces the cost of the map. Again, British maps reserve stippling ror mixed or intermediate and transitional associations : Dr. Rübel uses stippling to indicate the chief forest trees. I am not convinced that this latter is the better course on the whole; but it has the advantage of permitting the indication, on one and the same map, of both the forest-trees and the ground vegetation.

The classification of the vegetation follows the well-known Swiss lines, as laid down by Professor Schröter. A number of "vegetation types" are regarded as the primary divisions; and these are successively divided into "formation groups," "formations," and "associations." The first four of the "vegetation types" are based largely on plant form, being (1) woods, (2) scrub, (3) tall herb ground (Hochstaudenflur), and (4) grass grounds (Grasfluren). The remaining "vegetation types" are determined more by habitat factors. The forest "formations" are dominated by (1) larch (Larix decidua), (2) Arolla pine (Pinus cembra), and (3) Engadine pine (Pinus sylvestris var. encadinensis, $\mathrm{Heer}^{2}$ ).

These forest or woodland "formations" are scarcely the "formations" of British phytogeographers. In the Engadine one finds, generally speaking, a continuous forest on the lower mountain slopes: there is a great deal of mingling of the larches and Arolla pines; and the Scots (or Engadine) pine is very local. The ground vegetation of the three forest types varies. That of the larch forest on the newer and fresher soils, is grassy: that of the forest of

1 The highest larch in Switzerland, according to Dr. M. Rikli, is in Valais, at $2,700 \mathrm{~m}$. (8,840 feet).

2 This variety is characterised by very short leaves, by the bark being red almost from top to bottom, by its yellow cones, and by its pointed crown. The habit of the tree allows a great deal of light to reach the ground. It is a very distinct-looking plant. 
Arolla pine, on older and somewhat acidic soils, consists of heathy undershrubs; and that of the forest of the Engadine pine, on wetter soils, contains much Vaccinium vitis-idaa. ${ }^{1}$

The scrub "vegetation type" is divided into two "formation groups," (1) the tall scrub and (2) the low scrub. The tall scrub shows two formations, (1) the scrub of green alder (Aluns viridis) and (2) the scrub of mountain pine (Pinus montana). The green alder scrub occurs on the mountain slopes, prefers situations where there is a flow of water, and usually follows the streams. The soil is thus not only well-watered, but the water is well-aërated. The scrub is static; and, seen from the outside, it appears as a dense, dark green mass of high bushes with few or no shrubby or arboreal associates. The mountain pine scrub also occurs on the mountain slopes, but in drier situations. In the Pyrenees, it may be added, Pinus montana forms high forest; whilst in Austria, it is often a low gnarled shrub.

Of the low scrub (Kleinsträucher) "formation group," Dr. Rübel recognises two "formations," (1) the dwarf shrub (Zwerggestrauch) vegetation and (2) the espalier shrub (Spaliergestrauch) vegetation. The former is perhaps the most widespread of the plant communities of the Engadine, and is consequently very prominent on the vegetation map. It often covers the ground in the woods of Arolla pines, and sometimes in the green alder scrub and the scrub of mountain pine. It ascends higher than the present tree limit or dwarf-tree limit; and some Swiss plant geographers look upon its upper limit as indicating the former upper limit of trees. In this formation, Dr. Rübel distinguishes the following associations:-Rhododendretum ferruginei, ${ }^{2}$ Vacciniëtum myrtilli; Callunetum vulgaris; Calamagrostidetum villosæ; Juniperetum nanæ; Arctostaphyletum uvæ-ursi. A community of Vaccinium vitis-idea is placed as a sub-association (Nebentypus) of the Vaccinietum myrtilli. The soil of this formation is shallow and acidic.

The espalier shrub "formation" of the Engadine is a low growing, light demanding, humus (acidic) demanding community which alternates with the dwarf-shrub associations. Dr. Rübel distinguishes an association of Azalea procumbens (with a subassociation of Vaccinium uliginosum), and an association of Dryas octopetala. Dr. Rübel would have liked to have found another term to designate this "formation," as Vaccinium uliginosum is a dwarf shrub and not an espalier shrub; but he has been unable to find a better word, and so continues to use this one known from Professor Schröter's works. The formation receives no special colour on the vegetation map.

I I have not noted any allusion to birch woods by Dr. Rübel; but there is a small community of Betula pubescens in the Val Roseg. During my short stay in the district, I only saw two plants of $B$. alba $(B$. verrucosa): these were near Pontresina.

It may be of interest to add that the following trees are dominant in types of forest in other parts of Switzerland:-Quevcus pubescens; $Q$. pubescens and Ostrya carpinifolia; Castanea sativa; Fagus sylvatica; Abies alba (A. pectinatu); Picea excelsa (2).

2 Rhododendretum hirsuti occurs on calcareous soils; but such soils are rather of limited extent in the Engadine. 
Passing over-for want of space-the extremely interesting "vegetation type" designated the tall herb ground (Hochstaudenflur), with its "formations" of " kar-herbage" (Karflur') and "lairherbage" (Lagerflur), we come to the "vegetation type" of grass grounds (Grasfluren). This is composed of the single "formation group" of grasslands (Wiesen), which is divided into three formations :-(1) manured grassland (Fettwiese), (2) moist grassland (Frischwiese), and (3) dry grassland (Trockenwiese). Here one may allude to the conflicting use of the terms Weide and Matte by different German-speaking phytogeographers. The Swiss (3) by Weide mean pasture or grazed grasslands; and by Matte they mean meadow or mown grassland. On the other hand, Professor Diels (4) by Wiese means grassland with tall herbage $(4$, p. 91$)$, and by Matte he means grassland with low herbage $(4$, p.96). Brockmann (5) makes several sub-divisions of meadow (Matte) depending on whether the manuring is regular or intermittent, whether the ground is sheltered or not, and whether the ground is siliceous or calcareous. Dr. Rübel describes in all twenty-seven "associations" of his three grassland "formations." Here he follows Brockmann (5) closely ; and we may add that one of the chief points of Brockmann's monograph of the Puschlav region-which adjoins the Engadineis its minute study of gr'assland " associations." Many of these, I suppose, would be regarded as "societies" by British plant geographers.

A group of Dr. Rübel's associations of moist grasslands deserves special comment, namely, the associations named snow hollows (Schneetälchen). This term was first used, and the communities designated by it, were first described by Oswald Heer. Schröter adopted the term, and described the community as an association. Brockmann raised the community to the rank of formation; and Rübel uses the term to cover a natural group of associations within the "Frischwiese." Warming $(6$, p. 319$)$ refers to the community as the "snow patch flora." The ground of the "Schneetälchen" is gently inclined, flat, or concave; and is in spring and early summer saturated with water from contiguous melting snow. As may be inferred, the snow hollows occur in Alpine and Arctic regions. The soil consists of cold, wet humus. On siliceous soils, the associations recognised by Dr. Rübel are (1) Antheliëtum, (2) Polytrichetum, (3) Salicetum herbaceæ, and (4) Alchemilletum pentaphylleæ, whilst on calcareous soils, a Salicetum reticulati occurs. Three at least of these associations are British, one having been first described for this country by Dr. W. G. Smith (7) to whom it was pointed out on Ben Lawers by Professor Schröter and Dr. Rübel on the recent International Phytogeographical Excursion (1911).

Brockmann has shown that the members of the association have means (hairs, etc.) to prevent water from penetrating the tissues even when the plants are submerged in water for two or three weeks.

' "Kar" is an Austrian geological term to denote hollows dug out by glaciers. "Karflur" is a term introduced by Kerner to denote the tall herbage which often occurs in such places. The word "Kar" has been adopted by the Swiss, and seems to have no English equivalent. Hence my term "karherbage." 
Rübel's fifth "vegetation type" is made up of swampy grounds (Sumpffluren), divided into two "formation groups," (1) "Hochmoor" associations (Hochmoorbestände) and (2) "Flachmoor" associations (Flachmoorbestände). The concepts of "Hochmoor" and "Flachmoor" have recently been discussed by Tansley (8) and Moss (9); and it is only necessary here to state that the "Flachmoor" of the Engadine would, very largely, be placed in the British moor formation and not in the fen formation, although of course in many parts of Switzerland, particularly in the lowland districts, true fen is largely developed. It may also be pointed out that one of Rübel's "Hochmoor" associations is dominated by Pinus montana, in the tree form, so that here, at all events, the determination of plant formations by plant form breaks down, as Dr. Rübel has two communities dominated by this species. The particular point has been discussed by Gradmann (10).

Dr. Rübel goes on to describe his sixth "vegetation type," the fresh water vegetation, and lastly his seventh "vegetation type," the stony grounds (Gesteinfluren). The latter are divided into three "formation groups," (1) rocky grounds (Felsfluren), (2) rubbly grounds (Geröll- and Schuttfluren), and (3) sandy and gravelly grounds (Sand-and Kiesfluren). The Felsfluren consist of a single "formation," namely, the Felsflur, the Geröll- and Schuttfluren of two "formations," namely (1) the fixed rubble (Schuttflur) and (2) the sliding rubble or screes (Geröllflur), and the sandy and gravelly grounds are represented by a single formation, namely, the alluvial ground (Alluvialflur). These include in all ten associations. It is worth while adding the special Swiss significance of a number of terms which are here used, taken from Schröter (11). "Blöcke" (boulders) are from $25 \mathrm{~cm}$. upwards in diameter. "Geröll" refers to the sliding screes, "Schutt" to stones which do not move down the mountain side. "Kies," or gravel, refers to stones which are rounded by water action. Eacl of these-"Geröll," "Schutt," and "Kies"- may be " gross" or "fein." "Grossgeröll," "Grossschut," and "Grosskies " have stones with a diameter of $2 \cdot 0-2.5 \mathrm{~cm}$., whilst "Feingeröll," "Peinschutt," and "Feinkies" have stones with a diameter of $0.2-2.0 \mathrm{~cm}$. The particles of sand are $0.025-$ $0.2 \mathrm{~cm}$. in diameter.

The second (floristic) part of Dr. Rübel's work is as important and as carefully done as the first; and it is worth while drawing special attention to the fact that in a large number of cases the altitudes reached by species are given, and that these altitudes are in numerous cases higher than any previously recorded.

Although the concepts of vegetation units in Dr. Rübel's monograph are not strictly comparable with those that are adopted in this country, it is obvious that they (the Swiss concepts) serve quite well to describe the vegetation of the mountainous districts of Central Europe; and I have purposely refrained from any criticism of the Swiss views. The time is not ripe for a settlement of the vexed questions which are involved. It is my strong opinion that what is needed at present is not controversy, but a thorough understanding of each other's point of view; and if this review has been of a rather formal character, my excuse is that I wished to give some assistance to the younger and more serious-minded British ecologists in their efforts to become familiar with the phyto- 
geographical work of recent Swiss phytogeographers. As for rival schemes for the expression of the facts, it is certain that in the end the fittest scheme will survive; but there is, in my opinion, no hope that the process of the elimination of the unfit schemes will be completed during the life-time of the present generation of ecologists. Dr. Rübel's monograph concludes with a long list of references to the literature cited in the work, and with a full index.

\section{LIST OF REFERENCES.}

1. Woodhead, T. W. "Plant Geography and Ecology in Switzerland," in The Naturalist (May and June, 1908). (This paper gives a very useful account, with references, of the nature and extent of the phytogeographical work of Swiss botanists).

2. Brockmann-Jerosch, H. and M. "Die natürlichen Wälder der Schweiz" (Zürich, 1910).

3. Schröter, C. " Matten und Weiden der Schweiz" (1903).

4. Diels, L. "Pflanzengeographie" (Leipzig, 1908. Price One Shilling. Gives a useful and summarised view of the subject from the German point of view).

5. Brockmann-Jerosch, H. "Die Flora des Puschlav, Bezirk Bernina, Kanton Graubunden und ihre Pflanzengesellschaften." Leipzig (W. Engelmann), 1907. (A very complete monograph of the vegetation of a portion of south-eastern Switzerland).

6. Warming, E. "Ecology of Plants." Oxford, 1909.

7. Smith, W. G. "Anthelia: an Arctic-Alpine Plant Association." Scottish Bot. Rev., 1 (1912).

8. Tansley, A. G. "Types of British Vegetation" (Camb. Univ. Press), 1911, pp. 209-212.

9. Moss, C. E. "Vegetation of the Peak District." (Camb. Univ. Press), 1913.

10. Gradmann, R. "Über Begriffsbildung in der Lehre von den Pflanzenformationen." Engler's Bot. Jahrb., Beibl. 99, (1909).

11. Schröter, C. "Das Pflanzenleben der Alpen." (Zürich, 1904-1908).
C. E. MOSS. 
This document is a scanned copy of a printed document. No warranty is given about the accuracy of the copy. Users should refer to the original published version of the material. 